\title{
Keberlanjutan Sistem Penyediaan Air Minum Berbasis Komunitas (Studi Kasus: Hippam Mandiri Arjowinangun, Kota Malang)
}

\section{Sri Maryati ${ }^{1}$}

Kelompok Keahlian Sistem Infrastruktur Wilayah dan Kota

Sekolah Arsitektur, Perencanaan dan Pengembangan Kebijakan (SAPPK)

Institut Teknologi Bandung, Bandung, Indonesia

\section{Natasha Indah Rahmani}

Kelompok Keahlian Sistem Infrastruktur Wilayah dan Kota

Sekolah Arsitektur, Perencanaan dan Pengembangan Kebijakan (SAPPK)

Institut Teknologi Bandung, Bandung, Indonesia

\author{
Anggit Suko Rahajeng \\ Jurusan Perencanaan Wilayah dan Kota \\ Institut Teknologi Kalimantan, Balikpapan, Indonesia
}

Artikel Masuk : 21 Juni 2018

Artikel Diterima : 25 Juli 2018

Tersedia Online : 31 Agustus 2018

\begin{abstract}
Abstrak: Keterbatasan pemerintah dalam memenuhi kebutuhan air minum mendorong penerapan program pembangunan Sistem Penyediaan Air Minum (SPAM) yang dikelola oleh kelompok masyarakat, salah satunya dalam bentuk Himpunan Penduduk Pemakai Air Minum (Hippam). Isu penting dalam penyediaan air minum berbasis komunitas adalah keberlanjutan. Salah satu faktor yang mendukung keberlanjutan dalam penyediaan air minum adalah kelembagaan. Kelembagaan berhubungan dengan sistem pengelolaan, pemeliharaan dan pembiayaan, serta memiliki peran dalam pemilihan teknologi dan pengambilan keputusan. Tujuan penelitian ini adalah untuk mengeksplorasi kondisi kelembagaan sebagai faktor yang menentukan keberlanjutan pengelolaan air berbasis komunitas. Studi ini juga bertujuan untuk mengembangkan kerangka dalam penilaian kelembagaan penunjang keberlanjutan dalam penyediaan air minum berbasis komunitas. Dalam penelitian ini Hippam Mandiri Arjowinangun (HMA) di Kota Malang, Provinsi Jawa Timur dipilih sebagai kasus studi. HMA beroperasi sejak tahun 1994 dan sampai dengan saat ini masih beroperasi. Keberlanjutan HMA dilihat dari sisi penerapan prinsip-prinsip kelembagaan penunjang keberlanjutan sangat menarik untuk dikaji. Metode penelitian yang digunakan adalah penelitian kualitatif dengan membandingkan tolok ukur prinsip kelembagaan penunjang keberlanjutan dengan prinsip kelembagaan yang diterapkan pada HMA. Hasil analisis menunjukkan bahwa HMA telah menerapkan prinsipprinsip kelembagaan penunjang keberlanjutan. Namun demikian, terdapat beberapa hal yang perlu mendapat perhatian dalam keberlanjutan HMA, yaitu penetapan lingkup batasan, yang meliputi penentuan batas-batas sumber air yang digunakan, atribut khusus bagi pengguna, dan
\end{abstract}

\footnotetext{
${ }^{1}$ Korespondensi Penulis: Kelompok Keahlian Sistem Infrastruktur Wilayah dan Kota Sekolah Arsitektur, Perencanaan dan Pengembangan Kebijakan (SAPPK) Institut Teknologi Bandung, Bandung, Indonesia Email: smaryati@pl.itb.ac.id
} 
aturan pemanfaatan air. Penelitian ini juga menghasilkan kerangka untuk menilai kondisi keberlanjutan sistem penyediaan air minum berbasis komunitas dari sisi kelembagaan.

Kata Kunci: Hippam mandiri Arjowinangun; keberlanjutan; kelembagaan; penyediaan air minum berbasis komunitas; sumber daya milik bersama

\begin{abstract}
Limited capacity of government on drinking water supply has demanded the implementation of Community Based Water Supply System, one of them in the form of a Drinking Water User Association (Hippam). An important issue in community-based water supply is sustainability, from which institutions play a critical factor in the sustained provision of drinking water. Institutions relate to management, maintenance and financing systems, and contribute to technology selection and decision making. The purpose of this study is to explore the institutional conditions as a determinant factor for the sustainability of community-based water management. The study also aims to develop a framework for sustainable institutional assessment in community-based drinking water supply. In this study Hippam Mandiri Arjowinangun (HMA) in Malang City, East Java Province was chosen as a case study. HMA has been operating since 1994. The sustainability of HMA regarding applying the principles of institutional support for sustainability was very interesting as a case. The research method applied qualitative research by comparing the benchmark of institutional principles of sustainability with institutional principles applied to HMA. The result shows that HMA has applied the principles of institutional support for sustainability. However, some issues should be addressed in the HMA sustainability include the delineation of the water source boundary, specific attributes for the users, and the rules of water utilization. The study has also produced an assessment framework for the sustainability of community-based drinking water supply systems from the institutional perspective.
\end{abstract}

Keywords: common pool resources; community-based water supply provision; Hippam mandiri Arjowinangun; institutions; sustainability

\title{
Pendahuluan
}

Air minum merupakan kebutuhan dasar manusia. Akses terhadap air minum merupakan salah satu target dalam Sustainable Development Goals(SDGs), yang dinyatakan dalam tujuan keenam, yaitu pada tahun 2030 semua masyarakat harus mempunyai akses terhadap air minum. Tujuan keenam dalam SDGs ini terkait dengan tujuan-tujuan lainnya, antara lain tujuan ke-11 yaitu kota dan komunitas yang berkelanjutan.

Di Indonesia pemenuhan kebutuhan akan air minum untuk masyarakat dilakukan oleh pemerintah dalam bentuk sistem penyediaan air minum publik oleh Perusahaan Daerah Air Minum (PDAM). Namun demikian, cakupan pelayanan PDAM pada saat ini masih rendah. Pemenuhan kebutuhan air bagi masyarakat yang tidak terlayani oleh sistem publik dilakukan secara individual dan komunal (kelompok). Sistem komunal umumnya merupakan sistem yang berbasis komunitas. Sistem berbasis komunitas sangat berperan dalam peningkatan akses terhadap air minum. Dalam rangka meningkatkan akses terhadap air minum, tidak hanya diperlukan investasi dan pembangunan infrastruktur, tetapi juga kesediaan masyarakat secara berkelompok untuk melakukan pemenuhan sendiri (self-supply) sebagai strategi yang sifatnya sementara (Bisung dkk., 2014).

Sistem berbasis komunitas mempunyai beberapa bentuk, yaitu yang dikembangkan oleh masyarakat secara mandiri dan yang dikembangkan dengan bantuan pemerintah. Sistem berbasis komunitas banyak ditemukan di negara berkembang (Hope, 2015; Schouten \& Moriarty, 2003). Pendekatan ini banyak digunakan karena terbatasnya penyediaan air minum oleh pemerintah atau sektor swasta. Sistem ini menekankan keterlibatan masyarakat dalam implementasi, operasi, dan pemeliharaan (Bakker, 2008). 
Salah satu isu dalam penyediaan air minum berbasis komunitas adalah keberlanjutan. Pada tahun 2017, dilaporkan penyediaan air minum berbasis masyarakat di 15 kabupaten/kota memiliki kinerja di bawah standar dan 659 Himpunan Penduduk Pemakai Air Minum (Hippam) sudah tidak berfungsi (BPSPAMS, 2017). Salah satu faktor yang menyebabkan kegagalan dalam penyediaan air minum berbasis komunitas adalah kelembagaan yang belum mantap (BAPPENAS, 2003).

Tujuan penelitian ini adalah untuk mengeksplorasi kondisi kelembagaan sebagai faktor yang menentukan keberlanjutan pengelolaan air berbasis komunitas. Selain itu, studi ini juga bertujuan untuk mengembangkan kerangka dalam penilaian kelembagaan penunjang keberlanjutan dalam penyediaan air minum berbasis komunitas. Studi ini penting untuk dilakukan mengingat penyediaan air minum berbasis komunitas akan semakin berkembang di masa yang akan datang. Jumlah penduduk yang terus meningkat tidak dapat diikuti oleh penyediaan air minum publik. Penyediaan air minum berbasis komunitas merupakan sebuah alternatif untuk memenuhi kebutuhan masyarakat terhadap air bersih.

Obyek penelitian adalah Hippam Mandiri Arjowinangun (HMA) di Kota Malang, Provinsi Jawa Timur (lihat Gambar 1 dan Gambar 2). HMA merupakan Hippam terbesar di Kota Malang dan sebagai Hippam unggulan Provinsi Jawa Timur yang beroperasi sejak tahun 1994. HMA dipilih sebagai studi kasus karena dianggap sebagai Hippam yang berkelanjutan dengan jangka waktu operasional yang cukup lama dan prestasinya sebagai Hippam unggulan. Penerapan prinsip-prinsip kelembagaan penunjang keberlanjutan pada HMA sangat menarik untuk dikaji.

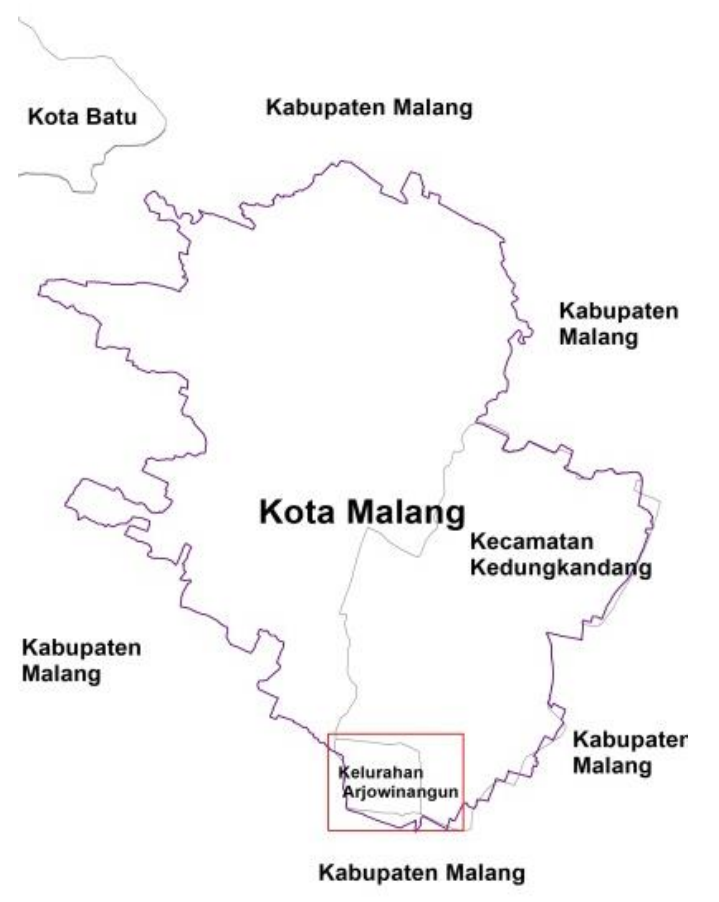

Sumber: Modifikasi dari BIG, 2017

Gambar 1. Peta Lokasi Kelurahan Arjowinangun 


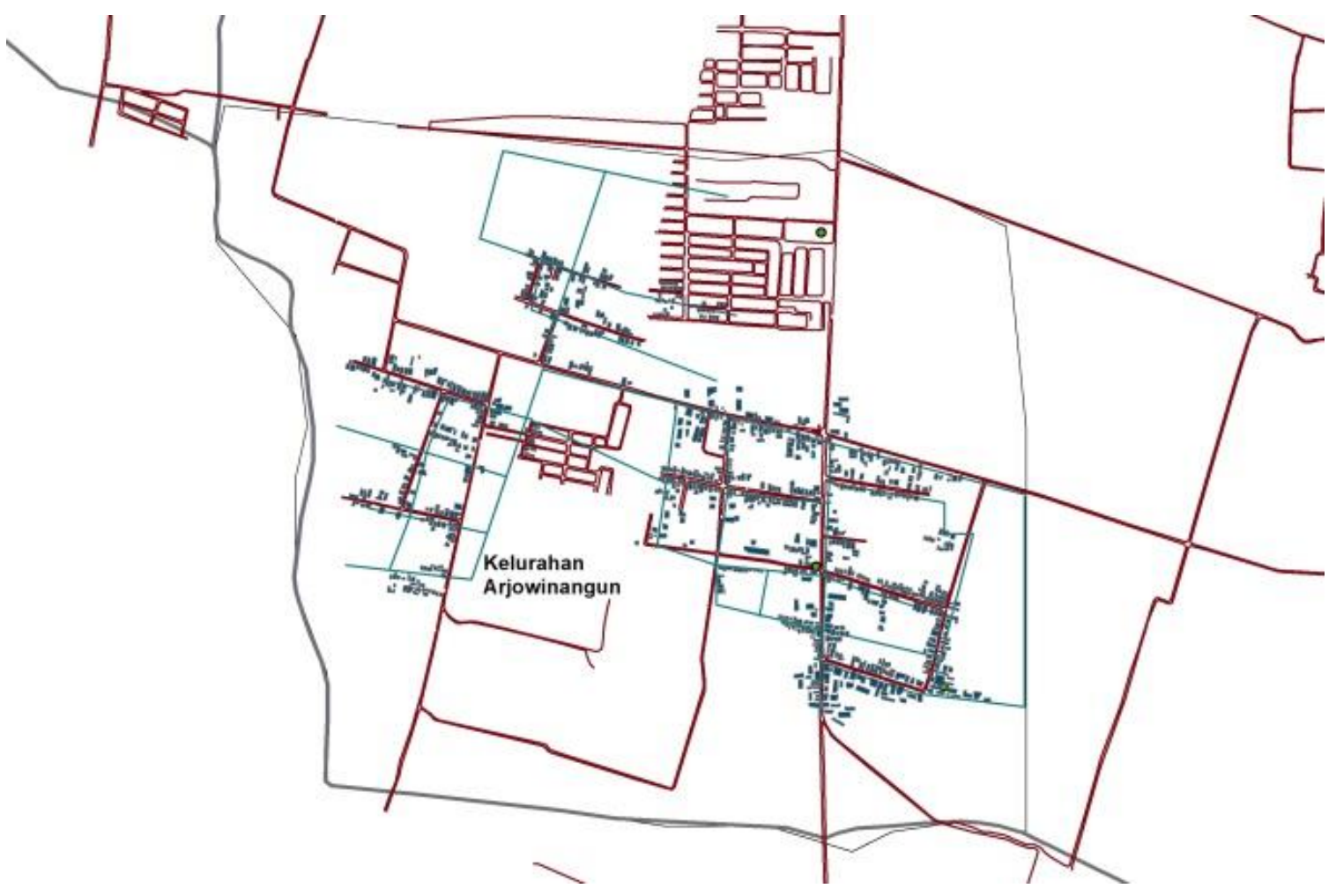

Sumber: Hippam, 2016

Gambar 2. Peta Persebaran Pengguna HMA

\section{Tinjuan Literatur}

\section{Penyediaan Air Minum berbasis Komunitas dan Common Pool Resources}

Sistem penyediaan air minum berbasis komunitas terbagi atas sistem perkotaan dan perdesaan. Kedua sistem ini berbeda karena perbedaan jumlah penduduk, kepadatan penduduk dan kondisi sosial. Berdasarkan penelitian yang dilakukan oleh Adams \& Zulu (2015), masyarakat kota berpartisipasi dalam bentuk uang dan menyerahkan pengelolaan pada pihak lain. Pengelolaan air minum di wilayah kota terbiasa diorganisir oleh suatu lembaga (Akbar \& Prabatmodjo, 2013). Tidak ada tokoh maupun tradisi yang mengikat dalam pengeloaan air minum seperti pada wilayah perdesaan.

Pengelolaan sistem penyediaan air minum berbasis komunitas berpotensi untuk dilihat dari sudut pandang pengelolaan barang milik bersama (common pool resources/CPR). CPR didefinisikan sebagai barang yang sulit namun memungkinkan untuk mendefinisikan penggunanya dan mengeluarkan pengguna lainnya. Lebih lanjut, dalam CPR penggunaan barang oleh seseorang dapat mengurangi manfaat pengguna lain (Ostrom, 1990). Sebagian besar sumber daya alam yang digunakan oleh banyak individu dapat diklasifikasikan sebagai CPR. CPR dapat berupa sistem alami maupun sistem buatan, seperti air tanah, irigasi, hutan, lahan, komputer, internet. Pengguna sumber daya juga menghadapi tantangan. Pengguna sumber daya membutuhkan asosiasi yang merupakan tempat untuk berbagi informasi (Ostrom, 2000).

Penyediaan infrastruktur air minum berbasis komunitas dengan menggunakan sumber air sulit untuk membatasi pengguna sumber air tersebut. Sebagai contoh, infrastruktur air berbasis komunitas yang menggunakan sumber mata air akan sulit mendefinisikan pengguna sumber air tersebut. Ekstraksi air pada sumber air yang dilakukan oleh seorang pengguna 
akan mempengaruhi manfaat yang diterima oleh pengguna lain. Keberadaan eksternalitas dan manfaat kolektif menunjukkan bahwa intervensi pada tingkat komunitas akan menghasilkan manfaat optimal (Dickin dkk., 2017).

\section{Keberlanjutan Penyediaan Air Minum Berbasis Komunitas}

Sistem berbasis komunitas umumnya menggunakan pendekatan pengelolaan bottomup. Pendekatan ini dilakukan berdasarkan kepercayaan bahwa komunitas dapat secara efektif mengelola pelayanan air minum melalui aksi kolektif karena adanya modal sosial seperti adanya jaringan sosial dan norma-norma (Zuka, 2013). Modal sosial diidentifikasi sebagai penentu yang utama dari aksi bersama (collective action). Hal ini merupakan hal yang sangat penting dalam konservasi dan pengelolaan CPR.

Salah satu persoalan yang dihadapi oleh sistem penyediaan air minum berbasis komunitas adalah keberlanjutan dari sistem tersebut (Ducrot, 2017). Keberlanjutan infrastruktur didefinisikan sebagai infrastruktur yang beroperasi terus-menerus, menjalankan fungsi yang memuaskan dan penggunaan yang efektif (UNICEF, 2010). Keberlanjutan sistem sebagian besar ditentukan oleh faktor institusional (Agrawal \& Chhatre, 2006; Dickin dkk., 2017; Ducrot, 2017; Lejano \& Fernandez de Castro, 2014). Dickin dkk. (2017) menunjukkan bahwa institusi dan kelembagaan, seperti jejaring sosial, kepemimpinan lokal, dan kondisi lingkungan yang menunjang sangat menentukan keberhasilan aksi bersama dan keberlanjutan sistem. Ricks (2016) menekankan bahwa organisasi lokal dalam aksi bersama dalam pengelolaan barang milik bersama memegang peranan dalam keberhasilan aksi bersama tersebut dibandingkan dengan sistem tersentralisasi.

Beberapa studi telah dilakukan untuk mengetahui faktor-faktor yang berpengaruh dalam pengelolaan barang milik bersama. Beberapa faktor yang berpengaruh selain institusi diantaranya adalah faktor biofisik, ekonomi dan demografi, sosial dan politik (Agrawal dkk., 2013; Agrawal \& Chhatre, 2006), modal sosial (Bisung dkk., 2014), serta sosial-ekologi (Kimbrough \& Vostroknutov, 2015).

\section{Kerangka Penilaian Keberlanjutan Penyediaan Air Minum berbasis Komunitas}

Suatu sumber daya jika terus-menerus diambil tanpa adanya pengelolaan yang baik dan jelas akan menyebabkan degradasi sumber daya. Fenomena ini biasa disebut dengan tragedy of commons (Schlager, 2004). Tragedy of commons menjelaskan kondisi eksploitasi berlebihan suatu sumber daya untuk kepentingan pribadi yang dilakukan oleh sekelompok individu (Hardin, 1968). Menurut Hardin (1968), kegagalan dalam pengelolaan barang milik bersama (tragedy of commons) dapat diselesaikan melalui intervensi pemerintah atau transaksi pasar. Kegagalan dalam pengelolaan CPR disebabkan oleh tidak terbatasnya akses terhadap sumber daya. Ostrom (1990) memperbaiki hipotesa ini dengan menyatakan bahwa pengelolaan berbasis masyarakat dapat memperbaiki kondisi ini. Institusi sangat berperan dalam penggunaan sumber daya lokal dan hasil dari penggunaan sumber daya yang dapat diperbaharui, seperti hutan, irigasi, air bersih, dan perikanan (Ostrom, 1990).

Tragedy of commons ini bisa berlaku pada berbagai sumber daya dan terkadang terdapat salah pemikiran khususnya terkait sumber daya yang dapat diperbarui. Sumber daya yang dapat diperbarui dianggap dapat diambil manfaatnya sesuai keinginan tanpa adanya sistem pengelolaan tertentu (Schlager, 2004).

Salah satu sumber daya yang diberikan label sumber daya yang dapat diperbarui namun pada kenyataannya sangat terbatas bagi sebagian besar penduduk adalah air. Meskipun air termasuk sumber daya yang dapat diperbarui, tidak semua masyarakat dapat menikmati air yang layak dikarenakan berbagai faktor, salah satunya adalah pengelolaan sumber air dan kelembagaan yang membuat sulitnya akses terhadap air minum. Aturan dan lingkup batas yang jelas dari sebuah pengelolaan sumber daya penting untuk diatur dalam mengelola sebuah sumber daya (Ostrom, 2000). Pada kenyataannya, pengelolaan sumber 


\section{Keberlanjutan Sistem Penyediaan Air Minum Berbasis Komunitas ...}

daya milik bersama tidak dapat diselesaikan hanya dengan satu sistem mekanisme pengelolaan (Fisher dkk., 2010).

Ostrom (1990) menginisiasi sebuah kerangka dasar dalam pengelolaan sumber daya berkelanjutan. Berdasarkan kerangka yang dikembangkan oleh Ostrom (1990), terdapat delapan prinsip pengelolaan sumber daya berkelanjutan, yaitu 1) batasan; 2) biaya dan manfaat; 3) aturan; 4) pengawasan; 5) sanksi; 6) mekanisme penyelesaian konflik; 7) pengakuan atas hak pengelolaan; dan 8) pengelolaan yang berjenjang. Selain itu, Ostrom (2000) menyatakan perlunya prinsip-prinsip berikut bagi pengelola CPR, yaitu 1) ketergantungan terhadap sumber daya; 2) pengetahuan yang sama tentang kondisi sistem; 3) tingkat diskonto yang rendah; 4) kepercayaan satu sama lain; 5) bebas dari pengaruh luar; dan 6) dapat dipercaya dan mempunyai jiwa kepemimpinan. Prinsip-prinsip tersebut menjadi dasar beberapa peneliti untuk mengembangkan konsep pengelolaan sumber daya berbasis masyarakat yang berkelanjutan. Agrawal (2001) menyatakan bahwa dalam pengelolaan CPR perlu diterapkan prinsip-prinsip sebagai berikut: 1) batasan sumber daya; 2) batasan pengguna; dan 3) hubungan antara sumber daya dan pengguna. Schlager (2004) menegaskan bahwa dalam pengelolaan CPR perlu adanya batasan anggota kelompok dan kesepakatan berdasarkan tujuan bersama. Selain kondisi tersebut, menurut Ostrom (2000), sumber daya yang dikelola harus bermanfaat tidak hanya untuk beberapa orang saja namun juga untuk kelompok lingkungan dan pengguna secara luas.

Berdasarkan kerangka yang dikembangkan oleh Agrawal (2001), Ostrom (1990, 2000) dan Schlager (2004), maka dapat disintesa kerangka penilaian keberlanjutan penyediaan air minum berbasis komunitas, seperti dapat dilihat pada Tabel 1 .

Tabel 1. Kerangka Penilaian Keberlanjutan Penyediaan Air Minum Berbasis Komunitas

\begin{tabular}{|c|c|c|c|}
\hline Prinsip & Kriteria & Indikator & Keterangan \\
\hline \multirow[t]{2}{*}{ Batasan } & $\begin{array}{l}\text { Sumber daya yang } \\
\text { digunakan memiliki } \\
\text { batasan yang jelas }\end{array}$ & $\begin{array}{l}\text { Delineasi sumber } \\
\text { daya }\end{array}$ & $\begin{array}{l}\text { Sumber air yang digunakan memiliki } \\
\text { batasan wilayah yang jelas dengan } \\
\text { ukuran yang jelas }\end{array}$ \\
\hline & & $\begin{array}{l}\text { Delineasi area } \\
\text { sumber daya yang } \\
\text { boleh digunakan }\end{array}$ & $\begin{array}{l}\text { Dari batasan wilayah sumber air yang } \\
\text { digunakan harus bisa diidentifikasi area } \\
\text { yang boleh digunakan sebagai sumber } \\
\text { daya bersama }\end{array}$ \\
\hline Manfaat & $\begin{array}{l}\text { Batasan yang jelas } \\
\text { untuk orang-orang } \\
\text { yang berhak mendapat } \\
\text { manfaat dari sumber } \\
\text { daya tersebut }\end{array}$ & $\begin{array}{l}\text { Delineasi } \\
\text { jangkauan } \\
\text { pelayanan }\end{array}$ & $\begin{array}{l}\text { Wilayah atau jumlah masyarakat yang } \\
\text { dapat terlayani oleh sumber air yang ada } \\
\text { harus terdefinisi }\end{array}$ \\
\hline \multirow[t]{6}{*}{ Aturan } & $\begin{array}{l}\text { Penyelenggaraan dan } \\
\text { pembuatan aturan yang }\end{array}$ & Kondisi sosial & $\begin{array}{l}\text { Identifikasi kondisi sosial masyarakat } \\
\text { pengguna air }\end{array}$ \\
\hline & $\begin{array}{l}\text { harus sesuai dengan } \\
\text { karakteristik }\end{array}$ & Kondisi ekonomi & $\begin{array}{l}\text { Identifikasi kondisi ekonomi masyarakat } \\
\text { pengguna air }\end{array}$ \\
\hline & masyarakat dan & Waktu pemakaian & Batasan waktu pemakaian air \\
\hline & norma/aturan yang & Tarif & Tarif untuk pemakaian sumber daya \\
\hline & $\begin{array}{l}\text { berlaku di lingkungan } \\
\text { tersebut }\end{array}$ & $\begin{array}{l}\text { Jumlah } \\
\text { pemakaian }\end{array}$ & Jumlah pemakaian yang diizinkan \\
\hline & & $\begin{array}{l}\text { Keinginan untuk } \\
\text { mengikuti aturan }\end{array}$ & $\begin{array}{l}\text { Kesediaan pengguna untuk mengikuti } \\
\text { aturan }\end{array}$ \\
\hline $\begin{array}{l}\text { Pengelolaan } \\
\text { yang } \\
\text { berjenjang }\end{array}$ & $\begin{array}{l}\text { Keterlibatan pengguna } \\
\text { dalam penyusunan } \\
\text { aturan dan } \\
\text { pengambilan keputusan }\end{array}$ & $\begin{array}{l}\text { Alur pembuatan } \\
\text { keputusan }\end{array}$ & $\begin{array}{l}\text { Adanya alur berjenjang dalam } \\
\text { pembuatan keputusan }\end{array}$ \\
\hline Pengawasan & $\begin{array}{l}\text { Pengawasan yang } \\
\text { efektif }\end{array}$ & $\begin{array}{l}\text { Anggota yang } \\
\text { terlibat } \\
\text { Pengawasan } \\
\end{array}$ & $\begin{array}{l}\text { Anggota yang diberi tanggung jawab } \\
\text { sebagai pengawas keberjalanan } \\
\text { pengelolaan air bersih }\end{array}$ \\
\hline
\end{tabular}


Lanjutan Tabel 1

\begin{tabular}{llll}
\hline \multicolumn{1}{c}{ Prinsip } & \multicolumn{1}{c}{ Kriteria } & \multicolumn{1}{c}{ Indikator } & \multicolumn{1}{c}{ Keterangan } \\
\hline & & Waktu & Waktu dilaksanakannya pengawasan \\
dilakukan secara berkala
\end{tabular}

Sumber: Agrawal, 2001; Ostrom, 1990, 2000; Schlager, 2004

\section{Metode Penelitian}

Penelitian ini merupakan penelitian kualitatif. Penelitian kualitatif menekankan pada eksplorasi dan pemahaman makna-makna yang terkandung dari sejumlah individu atau sekelompok orang (Creswell, 2010). Pendekatan studi kasus merupakan pendekatan yang digunakan dalam studi ini. Dalam pendekatan studi kasus, pencarian makna suatu fenomena akan lebih penting dibandingkan generalisasi data (Sugiyono, 2014), sehingga peneliti akan lebih fokus untuk melihat karakteristik HMA yang dilihat dari sudut pandang para pelaku HMA dan aktor lainnya yang terkait sesuai dengan prinsip pengelolaan air minum yang berkelanjutan. Observasi, wawancara dan penyebaran kuesioner kepada aktor-aktor yang berkaitan dengan pengelolaan HMA merupakan metode yang digunakan dalam pengumpulan data primer. Selain data primer, dalam penelitian ini juga digunakan data sekunder.

Eksplorasi terhadap kondisi kelembagaan didasarkan pada kerangka penilaian keberlanjutan sistem penyediaan air minum berbasis komunitas (lihat Tabel 1). Kerangka ini mengacu pada kerangka kelembagaan yang dikembangkan oleh Ostrom (1990), yang telah dimodifikasi dengan memasukkan juga prinsip-prinsip dalam Ostrom (2000), Agrawal (2001), dan Schlager (2004). Ostrom (1990) menyatakan bahwa terdapat delapan prinsip kelembagaan yang menunjang keberlanjutan. Prinsip tersebut sesuai dengan karakteristik sistem pengelolaan yang berbasis komunitas dan karakteristik perkotaan. Ostrom (1990) merumuskan prinsip kelembagaan yang mendukung keberlanjutan berdasarkan penelitian terhadap kelembagaan yang beroperasi dalam jangka waktu lama pada pengelolaan CPR. 
Penelitian pertamanya dilakukan pada kelompok pengelola lahan di lereng gunung dan hutan di Swiss dan Jepang, serta kelompok pengelola irigasi di Valencia dan Filipina untuk melihat prinsip apa saja yang dimiliki lembaga tersebut sehingga dapat beroperasi dalam jangka waktu lama.

Dalam penelitian ini digunakan sebelas narasumber yang dipilih dengan metode snowball sampling. Narasumber ini adalah pengurus dan pengguna HMA dan instansi terkait, yaitu Dinas Pekerjaan Umum dan Perumahan Rakyat (PUPR) Kota Malang, Asosiasi Hippam Kota Malang, Puskesmas Arjowinangun, Kelurahan Arjowinangun dan LPMK Arjowinangun. Informasi dari sebelas narasumber ini bersifat saling melengkapi satu dengan yang lainnya. Namun demikian, terdapat narasumber utama dari kesebelas narasumber ini untuk masingmasing indikator yang terdapat dalam kerangka penilaian kelembagaan penunjang keberlanjutan. Observasi dilakukan untuk mengetahui kondisi lingkungan, masyarakat, skala pelayanan, kondisi tandon, lokasi aset Hippam serta pelayanan administrasi secara langsung. Kuesioner diberikan kepada 143 responden yang merupakan masyarakat pengguna air minum yang dikelola HMA. Responden dipilih dengan metode purposive sampling. Informasi yang dieksplorasi dari 143 responden ini adalah informasi yang terkait dengan kondisi individual pengguna air, seperti kondisi sosial dan ekonomi, serta keinginan untuk mengikuti aturan. Data sekunder yang digunakan berupa dokumentasi kegiatan, buku referensi, karya ilmiah dan jurnal terkait.

\section{Hasil dan Pembahasan}

\section{Hippam Mandiri Arjowinangun}

Hippam Mandiri Arjowinangun (HMA) terletak di Kecamatan Kedungkandang, Kota Malang. HMA merupakan sebuah kelembagaan yang dibangun atas inisiatif masyarakat dibantu oleh pemerintah setempat yang bertanggung jawab dalam sistem penyediaan air minum. HMA sudah beroperasi sejak tahun 1994. Pendirian HMA dilatarbelakangi oleh kesulitan masyarakat dalam mengakses air minum dan ketidakmampuan masyarakat untuk berlangganan air minum publik yang disediakan PDAM.

Pada awal berdirinya HMA beranggotakan 153 pelanggan, dan pada tahun 2016 sudah memiliki 1031 pelanggan. Kenaikan jumlah pelanggan ini membuktikan bahwa keberadaan HMA dibutuhkan masyarakat dan menjadi salah satu lembaga yang diandalkan dalam penyediaan air minum di wilayah Kelurahan Arjowinangun. Pengurus inti HMA dipilih setiap empat tahun dan disahkan oleh Lurah Arjowinangun. Pengurus inti terdiri atas ketua, sekretaris, bendahara dan pengawas. Pengawas merupakan wakil dari Kelurahan Arjowinangun. Pengurus lainnya seperti administrasi, teknisi dan pencatat meter merupakan hasil dari pemilihan awal yang tidak memiliki batas waktu kepengurusan, karena dipilih sesuai keahlian masing-masing. Struktur organisasi HMA dapat dilihat pada Gambar 3.

Berdasarkan struktur organisasinya, terlihat bahwa hubungan antara pengurus inti dan aktor lain yang terlibat hingga pelanggan memiliki hierarki. Struktur organisasi ini sederhana dan jelas sesuai kebutuhan HMA. Berdasarkan struktur organisasi HMA tersebut terlihat bahwa organisasi ini berada di bawah lindungan pemerintah setempat yaitu Lurah Arjowinangun, dan tidak lepas dari pengawasan pihak yang berada di luar pengurus inti HMA. 


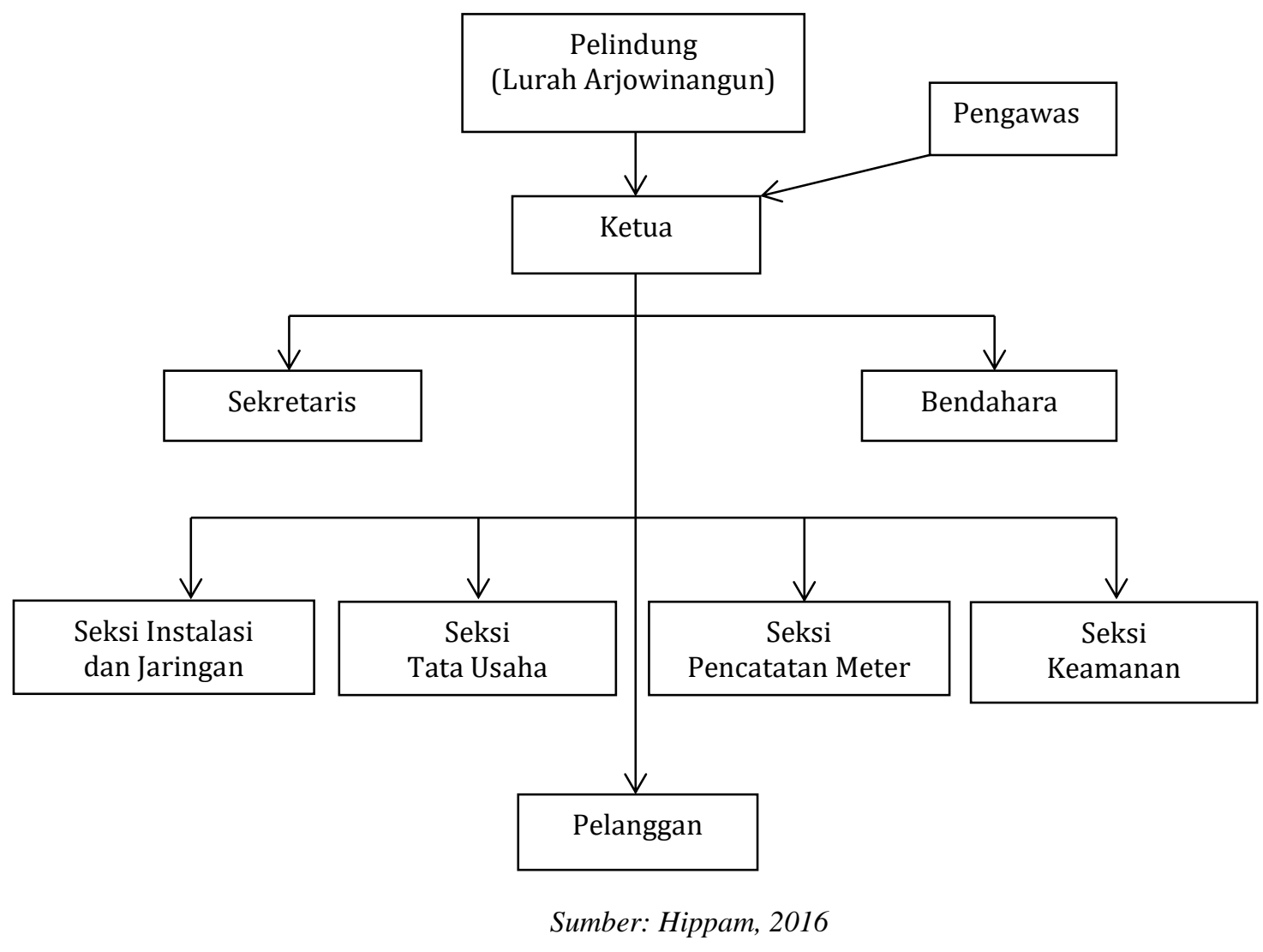

Gambar 3. Struktur Organisasi HMA

\section{Prinsip Pengelolaan Sumber Daya Berkelanjutan pada Hippam Mandiri Arjowinangun}

Bagian ini menjelaskan eksplorasi terhadap HMA dalam konteks kelembagaan pengelolaan sumber daya yang berkelanjutan.

\section{Batasan}

Penggunaan suatu sumber daya harus memiliki lingkup batasan yang jelas baik dari sisi batas wilayah maupun batas anggota yang bisa mendapatkan manfaat dari penggunaan sumber daya bersama. Dalam kasus HMA, lingkup batasan cakupan pelayanan sudah jelas terlihat. Wilayah pelayanan HMA meliputi lima RW yang terdiri atas RW 1, RW 2, RW 3, RW 7, dan RW 8 di Kelurahan Arjowinangun. Dalam memberikan pelayanan, HMA lebih mengutamakan masyarakat yang tidak mampu dan belum mempunyai akses air minum. Hal ini sesuai dengan alasan berdirinya HMA, yaitu untuk memberikan akses air minum kepada masyarakat yang tidak mampu. Selain memberikan akses air minum domestik, HMA juga melayani distribusi air minum untuk kebutuhan non-domestik seperti rumah sakit, SPBU, toko serta tempat peribadatan.

Sumber air yang digunakan oleh HMA adalah sungai bawah tanah yang berada di wilayah Kelurahan Arjowinangun. Anggota HMA adalah siapa pun yang menaati ketentuan dan memenuhi persyaratan pendaftaran meliputi KTP, KK dan biaya pendaftaran.

Pihak-pihak yang terkait dengan HMA adalah Kelurahan Arjowinangun, Asosiasi HIPPAM Kota Malang, Puskesmas Arjowinangun, LPMK Kelurahan Arjowinangun dan Dinas Pekerjaan Umum dan Perumahan Rakyat Kota Malang. Instansi-intansi tersebut memiliki fungsi pengawasan, pembinaan dan membantu dalam pemecahan masalah. Peran instansi tersebut diperlukan pada waktu-waktu tertentu dan tidak memiliki kewenangan untuk terlibat dalam pengelolaan HMA. 


\section{Manfaat}

Saat ini, keberadaan HMA bermanfaat bagi $1031 \mathrm{KK}$. Jumlah ini merupakan jumlah yang besar untuk skala pelayanan kelurahan. Manfaat lainnya yang diperoleh pengguna dengan adanya HMA selain adanya kemudahan dalam mengakses air minum dengan biaya yang terjangkau, juga membuka lapangan pekerjaan bagi staf.

Penetapan tarif didasarkan pada kebijakan pengurus, dengan menghitung rata-rata penggunaan air bersih maksimal bagi masyarakat berpendapatan rendah dan biaya operasional yaitu biaya listrik, gaji karyawan, pemeliharaan, aset dan cadangan biaya untuk pembangunan. Dengan mempertimbangkan kondisi ekonomi masyarakat, tarif yang diterapkan kurang lebih 50\% dari tarif PDAM. Keuntungan yang didapatkan disimpan dan digunakan untuk pemeliharaan dan pengembangan HMA. Pengguna HMA bisa menikmati air bersih selama 24 jam sesuai dengan kebutuhan masing-masing rumah tangga baik yang dekat dengan tandon maupun yang jaraknya jauh, demikian juga dengan pelanggan dari golongan sosial maupun jenis pelanggan lainnya.

\section{$\underline{\text { Aturan }}$}

Menurut Ostrom (1990), pengambilan keputusan apapun yang dilakukan dalam keberlanjutan pengelolaan sumber daya harus didasarkan pada kesepakatan bersama, artinya kesepakatan yang ada harus disetujui oleh seluruh anggota yang ada. Pengambilan keputusan bersama ini salah satunya bertujuan untuk mengendalikan suasana pengelolaan yang kondusif dan tidak adanya anggota yang melakukan tindakan yang merugikan dengan alasan tidak setuju dengan keputusan yang telah dibuat.

Dalam kepengurusan HMA, pengambilan keputusan dalam penetapan tarif, pemilihan pengurus, kegiatan HMA, dan lain-lain dilaksanakan oleh pengurus dengan melibatkan RT, RW, LPMK dan pihak Kelurahan Arjowinangun sebagai perwakilan masyarakat. Hasil dari pengambilan keputusan disampaikan kepada pengguna dan selanjutnya dilaksanakan serta dipatuhi bersama. Pengambilan keputusan diwakilkan pada beberapa orang yang dianggap dapat mewakili suara para anggota lainnya dan selanjutnya bagi para anggota yang tidak mengikuti pengambilan keputusan diberikan informasi, dan secara tidak langsung dipaksa untuk mematuhi aturan yang telah disepakati. Alur pengambilan keputusan yang ada di HMA ini rentan dengan ketidakpuasan beberapa pihak, namun selama ini hal-hal negatif yang mungkin muncul dari ketidakpuasan ditindaklanjuti dalam bentuk pengawasan dan sanksi.

Bentuk-bentuk pelaksanaan keputusan bersama antara lain adalah melaksanakan pengelolaan HMA apabila terpilih sebagai pengurus, melakukan pembayaran tagihan air bersih dan apabila tidak tepat waktu dalam pembayaran akan dikenakan denda hingga sanksi terberatnya adalah pemutusan aliran air, mendukung keputusan untuk melaksanakan kegiatan sosial yang dilakukan dua kali setahun, dan melaksanakan aturan yang tertuang pada Anggaran Dasar atau Anggaran Rumah Tangga (AD/ART) HMA.

\section{Pengelolaan Berjenjang}

Pengelolaan yang berjenjang ini penting apabila lembaga-lembaga yang terlibat berskala besar dan memiliki hierarki. HMA sendiri berdiri di bawah perlindungan lurah dan menjadi bagian dari Asosiasi Hippam Kota Malang yang memiliki hierarki di atas pengelola HMA. Meskipun terdapat lembaga-lembaga lain di luar pengelola itu sendiri, asosiasi Hippam hanyalah merupakan wadah tempat menyampaikan aspirasi, tidak ada kewenangan yang diserahkan pada Asosiasi Hippam Kota Malang terkait dengan pengelolaan Hippam di daerah. Hippam memiliki kewenangan dan hak pengelolaan sepenuhnya terhadap kelembagaannya di wilayah masing-masing. Pada Gambar 4 dapat dilihat berbagai instansi yang terlibat dalam pengelolaan HMA. 


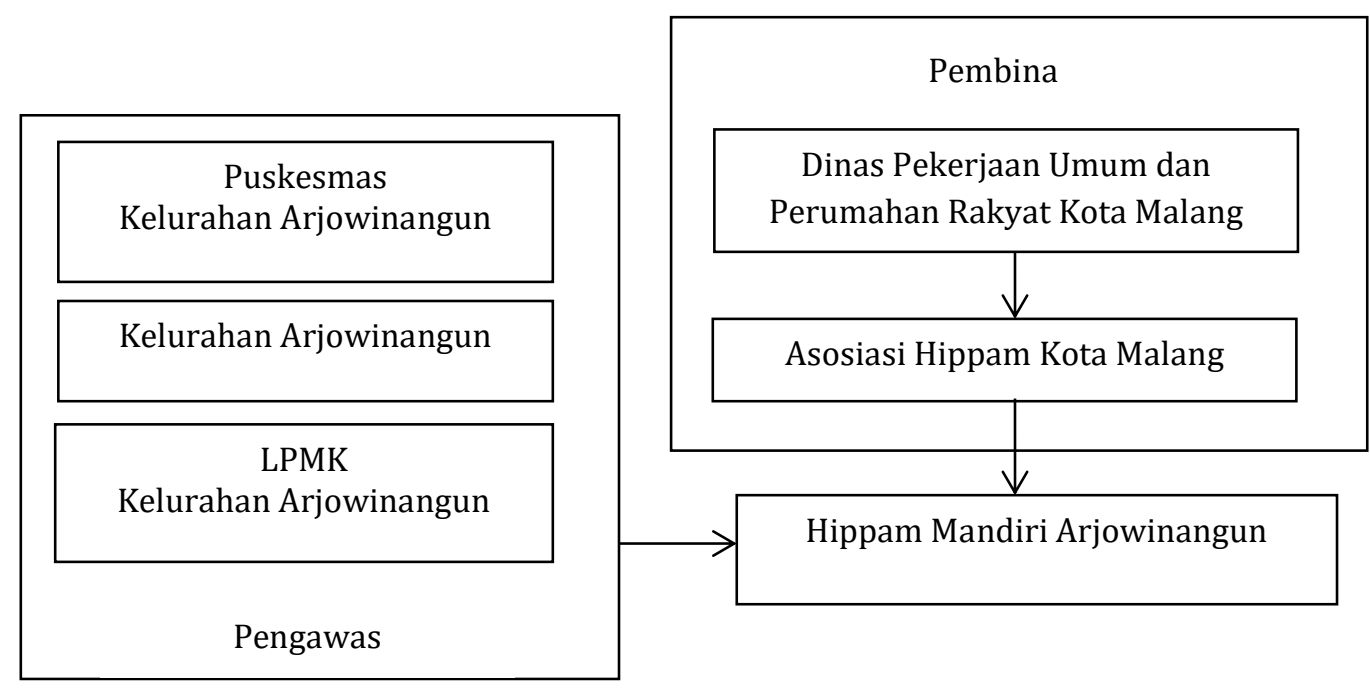

Sumber: Hippam, 2016

\section{Gambar 4. Hierarki Kelembagaan Pengelola HMA}

Pada Gambar 4 terlihat hierarki teratas adalah Dinas Pekerjaan Umum dan Perumahan Rakyat Kota Malang yang merupakan institusi yang memiliki kewenangan secara langsung dari pemerintah pusat untuk mengurusi keberlangsungan akses air di Kota Malang. Selanjutnya, terdapat Asosiasi Hippam yang menaungi aspirasi dan menjadi perpanjangan tangan antara pengelola Hippam dan dinas terkait.

\section{Pengawasan}

Terdapat dua bentuk pengawasan di HMA, yaitu pengawasan yang dilakukan oleh internal pengurus yaitu pengelola HMA itu sendiri dan juga pengawasan yang dilakukan oleh lembaga di luar HMA. Lembaga di luar HMA yang memiliki fungsi untuk mengawasi keberlangsungan pengelolaan HMA adalah Kelurahan Arjowinangun sebagai pemerintah lokal yang berhubungan langsung dengan pengelola sebagai pengawas dalam bidang administrasi, Puskesmas Arjowinangun yang bertugas dalam pengawasan kualitas air, dan LPMK Kelurahan Arjowinangun dibantu RT dan RW setempat sebagai aktor yang bertanggung jawab dalam pengawasan yang bersifat operasional.

Dilihat dari peran masing-masing lembaga di luar pengurus HMA, pengawasan yang ada terbagi atas tiga bagian yaitu pengawasan teknis, operasional, manajemen serta pemantauan kualitas air bersih. Penunjukan pengawas ini sendiri dilakukan oleh kelurahan, sedangkan pemantau kondisi sambungan dan meteran dipilih oleh masyarakat secara langsung. Monitoring operasional dan pengelolaan dilaksanakan oleh pengawas dari Kelurahan Arjowinangun.

\section{$\underline{\text { Sanksi }}$}

Pelaksanaan aktivitas dalam pengelolaan HMA tidak terlepas dari adanya pelanggaran-pelanggaran yang dilakukan oleh anggota HMA itu sendiri. Bentuk pelanggaran yang paling banyak terjadi adalah pelanggaran dalam keterlambatan pembayaran tagihan air. Pelanggaran ini jika tidak ditindak dengan tegas akan berdampak buruk bagi kinerja HMA. Salah satu dampak buruk yang ditimbulkan dari adanya pelanggaran ini adalah terhambatnya hal-hal yang bersifat operasional, terutama dalam hal pembayaran listrik. 
Sanksi yang diberikan oleh pengurus diberikan secara bertahap sesuai dengan aturan yang telah ditetapkan sebelumnya. Sanksi yang ditetapkan oleh HMA dicantumkan dalam struk pembayaran dan telah diinformasikan kepada masing-masing anggota HMA. Bentuk sanksi tersebut yaitu (1) pemberian denda apabila terlambat membayar sebesar Rp 3.000 tiap bulan; (2) pemberian surat peringatan setiap keterlambatan maksimal empat kali untuk memberikan kesempatan pada masyarakat melakukan pelunasan; dan (3) pemutusan jaringan apabila tidak ada pelunasan pembayaran dan tanggapan terhadap surat peringatan yang diberikan. Tahap terakhir yang diberikan adalah pemutusan jaringan air.

\section{Mekanisme Penyelesaian Konflik}

Pembuatan keputusan bersama yang dilakukan di HMA rentan akan konflik apabila perwakilan dari anggota yang telah diberi tanggung jawab tidak dapat mewakili keinginan para anggotanya, sehingga diperlukan mekanisme solusi konflik yang efektif apabila sebuah konflik muncul dan mengancam keberjalanan HMA. Sejak awal berdirinya hingga saat ini, konflik yang pernah terjadi pada pengelolaan HMA adalah konflik antara pengurus dan pengguna yang muncul akibat adanya ketidakpuasan anggota/pengguna akan kinerja HMA. Dalam hal ini mekanisme penyelesaian konflik dilakukan dengan mengadakan sebuah rapat bersama yang membahas konflik tersebut dan bermusyawarah untuk mendapatkan solusi terbaik. Berdasarkan pengalaman, keputusan yang diambil dari hasil rapat bersama adalah dengan melakukan pemilihan ulang pengurus HMA yang baru yang diharapkan dapat memenuhi kepuasan para anggota/pengguna HMA.

Selain konflik antara pengguna dan pengurus HMA, konflik lain yang pernah terjadi adalah konflik kesalahpahaman antara pengurus HMA dan Dinas PUPR Kota Malang. Pemicu terjadinya konflik adalah kerusakan SPAM yang terjadi akibat pembangunan yang dilakukan oleh Dinas PUPR Kota Malang. Penyelesaian konflik ini juga diselesaikan dengan musyawarah antar anggota dan mengeluarkan keputusan yang berujung pada klaim.

\section{Pengakuan Hak atas Pengelolaan}

Pengelolaan sumber daya yang berkelanjutan harus terbebas dari intervensi yang mungkin dilakukan oleh pihak luar pengurus yang dapat mengganggu harmonisasi keberjalanan pengelolaan (Ostrom, 1990). Salah satu cara untuk terbebas dari adanya intervensi oleh pihak luar adalah dengan mendapatkan pengakuan atas hak pengelolaan sumber daya yang ada. Pengakuan ini akan semakin kuat apabila memiliki landasan hukum yang jelas yang berlaku di wilayah tersebut. HMA telah mendapat pengakuan hukum sebagai penyedia air minum. Pengakuan yang ada tercantum dalam SK Menteri Hukum dan HAM Republik Indonesia Nomor AHU-0059015.01.07 Tahun 2016 tentang Pengesahan Pendirian Badan Hukum Perkumpulan Penduduk Pemakai Air Minum Arjowinangun melalui Akta Nomor 122 tanggal 14 April 2016 yang disahkan oleh notaris. Dengan adanya pengakuan atas hak pengelolaan yang jelas dan berlandaskan hukum yang berlaku di wilayah setempat, maka dapat dipastikan bahwa pengelolaan HMA terbebas dari pengaruh-pengaruh aktor luar yang mungkin mengganggu harmonisasi keberjalanan pengelolaan HMA. Pengakuan ini berarti bahwa pengelola HMA harus mampu mengurus pengelolaan sumber daya dengan baik dan mandiri.

Apabila dibandingkan antara penerapan prinsip kelembagaan HMA dengan kerangka yang telah dikembangkan, maka HMA telah menerapkan prinsip-prinsip kelembagaan yang mendukung keberlanjutan. Tabel 2 menunjukkan perbandingan antara pengelolaan HMA dan kerangka kelembagaan penunjang keberlanjutan. 
Tabel 2. Perbandingan Prinsip Kelembagaan HMA dengan Kerangka Kelembagaan Penunjang Keberlanjutan

\begin{tabular}{|c|c|c|c|}
\hline Prinsip & Kriteria & Indikator & Kelembagaan HMA \\
\hline \multirow[t]{2}{*}{ Batasan } & $\begin{array}{l}\text { Sumber daya } \\
\text { yang digunakan } \\
\text { memiliki batasan } \\
\text { yang jelas }\end{array}$ & $\begin{array}{l}\text { Delineasi } \\
\text { sumber daya }\end{array}$ & $\begin{array}{l}\text { Sumber daya yang digunakan merupakan } \\
\text { sumber air yang berada di Kelurahan } \\
\text { Arjowinangun, namun belum ada prediksi } \\
\text { mengenai kemampuan sumber air yang } \\
\text { dapat digunakan }\end{array}$ \\
\hline & & $\begin{array}{l}\text { Delineasi area } \\
\text { sumber daya } \\
\text { yang boleh } \\
\text { digunakan }\end{array}$ & $\begin{array}{l}\text { Sumber air yang digunakan adalah sungai } \\
\text { bawah tanah yang berada di lahan } \\
\text { Kelurahan Arjowinangun dan } \\
\text { dimanfaatkan oleh pengguna HMA }\end{array}$ \\
\hline Manfaat & $\begin{array}{l}\text { Batasan yang jelas } \\
\text { untuk orang-orang } \\
\text { yang berhak } \\
\text { mendapat manfaat } \\
\text { dari sumber daya } \\
\text { tersebut }\end{array}$ & $\begin{array}{l}\text { Delineasi } \\
\text { jangkauan } \\
\text { pelayanan }\end{array}$ & $\begin{array}{l}\text { Wilayah pelayanan HMA meliputi RW 1, } \\
\text { RW 2, RW 3, RW 7, dan RW } 8 \text { di } \\
\text { Kelurahan Arjowinangun }\end{array}$ \\
\hline \multirow[t]{6}{*}{ Aturan } & $\begin{array}{l}\text { Penyelenggaraan } \\
\text { dan pembuatan } \\
\text { aturan yang harus } \\
\text { sesuai dengan } \\
\text { karakteristik }\end{array}$ & Kondisi sosial & $\begin{array}{l}\text { Sebagian besar masyarakat pengguna } \\
\text { HMA merupakan pekerja swasta }(36 \%) \text {, } \\
\text { sedangkan sisanya merupakan pekerja } \\
\text { lepas seperti buruh tani, petani, tukang, } \\
\text { pemulung dan pensiunan }\end{array}$ \\
\hline & $\begin{array}{l}\text { masyarakat dan } \\
\text { norma/aturan yang } \\
\text { berlaku di }\end{array}$ & $\begin{array}{l}\text { Kondisi } \\
\text { ekonomi }\end{array}$ & $\begin{array}{l}\text { Dilihat dari mata pencaharian para } \\
\text { pengguna HMA merupakan golongan } \\
\text { ekonomi menengah ke bawah }\end{array}$ \\
\hline & lingkungan tersebut & $\begin{array}{l}\text { Waktu } \\
\text { pemakaian }\end{array}$ & $\begin{array}{l}\text { Masyarakat dibebaskan menggunakan air } \\
\text { selama } 24 \text { jam sesuai kebutuhan tanpa ada } \\
\text { batasan tertentu, sehingga dapat } \\
\text { mengancam keberlangsungan sumber } \\
\text { daya }\end{array}$ \\
\hline & & Tarif & $\begin{array}{l}\text { Terdapat peraturan terkait tarif, yaitu } \\
\text { semakin banyak pemakaian maka } \\
\text { pembayaran juga akan semakin mahal, } \\
\text { semua pengguna dapat menikmati air } \\
\text { minum selama } 24 \text { jam nonstop }\end{array}$ \\
\hline & & $\begin{array}{l}\text { Jumlah } \\
\text { pemakaian }\end{array}$ & $\begin{array}{l}\text { Tidak ada pembatasan jumlah pemakaian } \\
\text { karena telah diterapkan tarif progresif } \\
\text { terhadap pemakaian. Namun demikian } \\
\text { karena tarif yang ditentukan tidak terlalu } \\
\text { mahal, jumlah pemakaian seharusnya } \\
\text { dibatasi atau diberikan batas maksimal }\end{array}$ \\
\hline & & $\begin{array}{l}\text { Keinginan } \\
\text { untuk mengikuti } \\
\text { aturan }\end{array}$ & $\begin{array}{l}\text { Hasil kuesioner menyatakan } 6 \% \\
\text { responden setuju dan } 94 \% \text { sangat setuju, } \\
\text { bahwa pengurus HMA menetapkan tarif } \\
\text { dengan mengakomodasi biaya operasional } \\
\text { dan sesuai dengan kondisi masyarakat. } \\
\text { Masyarakat juga bersedia mengikuti } \\
\text { aturan }\end{array}$ \\
\hline $\begin{array}{l}\text { Pengelolaan } \\
\text { yang } \\
\text { berjenjang }\end{array}$ & $\begin{array}{l}\text { Keterlibatan } \\
\text { pengguna dalam } \\
\text { penyusunan aturan } \\
\text { dan pengambilan } \\
\text { keputusan }\end{array}$ & $\begin{array}{l}\text { Alur pembuatan } \\
\text { keputusan }\end{array}$ & $\begin{array}{l}\text { Pengambilan keputusan dilaksanakan oleh } \\
\text { pengurus HMA dengan melibatkan RT, } \\
\text { RW, LPMK dan pihak Kelurahan } \\
\text { Arjowinangun sebagai perwakilan } \\
\text { masyarakat. Partisipasi yang dilakukan } \\
\text { dalam bentuk perwakilan, sehingga } \\
\text { pengguna tidak terlibat secara langsung }\end{array}$ \\
\hline
\end{tabular}


Lanjutan Tabe/ 2

\begin{tabular}{|c|c|c|c|}
\hline Prinsip & Kriteria & Indikator & Kelembagaan HMA \\
\hline \multirow[t]{3}{*}{ Pengawasan } & $\begin{array}{l}\text { Pengawasan yang } \\
\text { efektif }\end{array}$ & $\begin{array}{l}\text { Anggota yang } \\
\text { terlibat } \\
\text { pengawasan }\end{array}$ & $\begin{array}{l}\text { 1. Pihak Puskesmas melakukan } \\
\text { pemantauan sebagai salah satu kewajiban } \\
\text { dan tugas yang diamanatkan dalam } \\
\text { undang-undang } \\
\text { 2. Pemantau kondisi sambungan dan } \\
\text { meteran dipilih oleh masyarakat secara } \\
\text { langsung } \\
\text { 3. Pengawasan administrasi dan keuangan } \\
\text { dilaksanakan oleh pengawas yang ditunjuk } \\
\text { oleh Lurah Arjowinangun } \\
\text { 4. Pengawasan kinerja dan kelancaran } \\
\text { operasional dilaksanakan oleh LPMK dan } \\
\text { Lurah Arjowinangun } \\
\text { Belum ada pemantau yang ditunjuk oleh } \\
\text { pengguna yang mengawasi administrasi, } \\
\text { keuangan, dan pelayanan }\end{array}$ \\
\hline & & $\begin{array}{l}\text { Waktu } \\
\text { pengawasan }\end{array}$ & $\begin{array}{l}\text { Pelaporan dilakukan secara rutin setiap } \\
\text { bulan sekali dan rapat minimal setahun } \\
\text { sekali untuk proses evaluasi }\end{array}$ \\
\hline & & $\begin{array}{l}\text { Bentuk } \\
\text { pengawasan }\end{array}$ & $\begin{array}{l}\text { Terdapat sistem penegakan pemantauan } \\
\text { yaitu pengawasan kondisi sambungan dan } \\
\text { meteran, pengawasan kualitas air bersih, } \\
\text { pengawasan administrasi keuangan dan } \\
\text { pengawasan kinerja serta kelancaran } \\
\text { operasional. }\end{array}$ \\
\hline \multirow[t]{3}{*}{ Sanksi } & $\begin{array}{l}\text { Sistem pemberian } \\
\text { sanksi }\end{array}$ & $\begin{array}{l}\text { Alur proses } \\
\text { pemberian } \\
\text { sanksi }\end{array}$ & $\begin{array}{l}\text { Pelanggan diberitahu mengenai peraturan } \\
\text { denda yang diberlakukan dan selanjutnya } \\
\text { pelanggar akan langsung ditindak sesuai } \\
\text { dengan jenis pelanggarannya }\end{array}$ \\
\hline & & $\begin{array}{l}\text { Tindak lanjut } \\
\text { pemberian } \\
\text { sanksi }\end{array}$ & $\begin{array}{l}\text { Akan dilakukan pemutusan jaringan } \\
\text { apabila sanksi yang diberikan sebelumnya } \\
\text { tidak dihiraukan }\end{array}$ \\
\hline & & Bentuk sanksi & $\begin{array}{l}\text { Sanksi yang diberikan berupa denda } \\
\text { hingga pemutusan aliran, namun masih } \\
\text { ada penyelesaian melalui jalur } \\
\text { kekeluargaan }\end{array}$ \\
\hline \multirow[t]{4}{*}{$\begin{array}{l}\text { Mekanisme } \\
\text { penyelesaian } \\
\text { konflik }\end{array}$} & $\begin{array}{l}\text { Mekanisme } \\
\text { penyelesaian konflik } \\
\text { yang efisien dan } \\
\text { efektif }\end{array}$ & $\begin{array}{l}\text { Alur } \\
\text { penyelesaian } \\
\text { konflik }\end{array}$ & $\begin{array}{l}\text { - Konflik pengurus dan pengguna } \\
\text { diselesaikan dengan pemilihan pengurus } \\
\text { sesuai keinginan masyarakat } \\
\text { - Konflik HMA dan Dinas PUPR } \\
\text { diselesaikan dengan melakukan perbaikan } \\
\text { dengan dana yang diberikan Dinas PUPR } \\
\text { dan dana HMA }\end{array}$ \\
\hline & & Tipe konflik & $\begin{array}{l}\text { Konflik yang ada berupa ketidakpuasan } \\
\text { dan kesalahan komunikasi antara pengurus } \\
\text { dan pengguna dan pengurus dan } \\
\text { lingkungan eksternal (Dinas PUPR) }\end{array}$ \\
\hline & & $\begin{array}{l}\text { Jangka waktu } \\
\text { penyelesaian } \\
\text { konflik }\end{array}$ & $\begin{array}{l}\text { Konflik yang ada diselesaikan dengan } \\
\text { segera dan tidak pernah berlarut-larut }\end{array}$ \\
\hline & & Pemicu konflik & $\begin{array}{l}\text { Konflik yang biasanya terjadi adalah } \\
\text { konflik antara pengurus dan pengguna } \\
\text { mengenai kinerja HMA. Konflik lainnya } \\
\text { berupa konflik antara lembaga sendiri dan } \\
\text { individu luar }\end{array}$ \\
\hline
\end{tabular}


Lanjutan Tabe/ 2

\begin{tabular}{ccll}
\hline \multicolumn{1}{c}{ Prinsip } & \multicolumn{1}{c}{ Kriteria } & \multicolumn{1}{c}{ Indikator } & \multicolumn{1}{c}{ Kelembagaan HMA } \\
\hline & & $\begin{array}{l}\text { Aktor yang } \\
\text { dipercaya untuk } \\
\text { menyelesaikan } \\
\text { konflik }\end{array}$ & $\begin{array}{l}\text { Pengurus Hippam dan anggota/pengguna } \\
\text { yang termasuk dalam keanggotaan HMA }\end{array}$ \\
Pengakuan & Pengelolaan sumber & $\begin{array}{l}\text { Pengakuan } \\
\text { dalam }\end{array}$ & SK Menteri Hukum dan HAM Republik \\
atas hak & daya yang terbebas & Indonesia Nomor AHU-0059015.01.07. \\
pengelolaan & dari pengaruh luar & $\begin{array}{l}\text { pengelolaan } \\
\text { sumber daya }\end{array}$ & Tahun 2016 \\
& & $\begin{array}{l}\text { Adanya } \\
\text { peraturan yang } \\
\text { mengatur hak }\end{array}$ & $\begin{array}{l}\text { HMA merupakan lembaga mandiri yang } \\
\text { berada di bawah strukur pemerintahan }\end{array}$ \\
& & Kelurahan Arjowinangun dan merupakan \\
& & & \\
& & &
\end{tabular}

Sumber: Analisis Penulis, 2017

\section{Kesimpulan}

Dalam studi ini telah dihasilkan suatu kerangka yang dapat digunakan untuk menilai penerapan prinsip kelembagaan penunjang keberlanjutan penyediaan air minum berbasis masyarakat. Kerangka ini juga dapat digunakan sebagai acuan dalam menyiapkan sistem penyediaan air minum berbasis komunitas. Berdasarkan hasil analisis dapat disimpulkan bahwa HMA telah menerapkan prinsip-prinsip kelembagaan penunjang keberlanjutan. Konsistensi dalam penerapan prinsip-prinsip ini telah menjadikan HMA dapat bertahan hingga saat ini. Namun demikian, terdapat prinsip yang belum optimal penerapannya, yaitu batasan. Dalam HMA belum ada penetapan batas-batas sumber air yang digunakan, demikian juga dengan prediksi kemampuan sumber air yang ada. Batasan merupakan prinsip penting dalam keberlanjutan suatu sistem penyediaan air minum karena tanpa adanya sumber air yang berkelanjutan, sistem yang ada juga tidak akan berkelanjutan. Masih terkait dengan prinsip batasan, pada HMA tidak terdapat atribut khusus yang ditujukan sebagai identitas yang membedakan masyarakat pengguna dan nonpengguna. Tanpa adanya identitas khusus, nonpengguna pun dapat memanfaatkan air yang dihasilkan dari HMA. Hal penting lainnya terkait prinsip aturan, HMA belum menetapkan aturan khusus yang mengatur pemanfaatan air minum dari segi waktu aliran dan volume maksimal penggunaan air. Meskipun sudah ada penetapan tarif yang dapat membatasi penggunaan air minum oleh pengguna, aturan yang mengatur konservasi air sangat diperlukan bagi keberlanjutan sistem. Hal menarik pada HMA adalah keterlibatan organisasi struktural pemerintahan dalam pembentukan dan operasi sistem ini. Dukungan dari pemerintah tentunya sangat diperlukan bagi keberlanjutan sistem.

\section{Rekomendasi}

Berkaitan dengan temuan hasil analisis, berikut ini sejumlah rekomendasi yang dapat diberikan untuk keberlanjutan Sistem Penyediaan Air Minum Berbasis Komunitas yang lebih baik mengacu pengalaman di Kelurahan Arjowinangun Kota Malang:

1. Menetapkan batas-batas sumber daya dan melakukan perhitungan debit sehingga dapat diprediksi potensi air minum yang dapat didistribusikan untuk masyarakat. Untuk menghindari penggunaan sumber daya yang berlebih dapat diterapkan batas maksimal penggunaan air dengan perhitungan rata-rata penggunaan air minum pada masing-masing kategori. Kesepakatan penggunaan maksimal harus diambil dengan persetujuan seluruh pengguna; 
2. Memberikan atribut khusus dalam bentuk kartu kendali yang berisi nama, nomor pelanggan dan pemakaian per bulan yang ditempel di rumah oleh pihak Hippam yang berfungsi memudahkan pencatat dan menghindari pemberian informasi atau manfaat kepada pihak yang bukan pengguna Hippam;

3. Melibatkan masyarakat dalam pengambilan keputusan dengan memilih wakil-wakil pengguna sebagai penyampai aspirasi yang ditunjuk secara bergilir. Meskipun sudah ada RT dan RW namun pengguna memiliki hak untuk ikut serta dalam pembuatan keputusan seperti yang tertuang dalam AD/ART HMA;

4. Menetapkan pemantau yang ditunjuk secara resmi oleh pengguna sebagai wakil pengguna dalam mengawasi jalannya operasional secara bergantian agar semua pengguna berpartisipasi dalam penegakan peraturan.

Lebih lanjut kerangka yang telah dimodifikasi dari Ostrom (1990), Ostrom (2000), Agrawal (2000), dan Schlager (2004) dapat digunakan untuk menilai kelembagaan sistem penyediaan air minum berbasis masyarakat. Melalui kerangka ini dapat diketahui hal-hal apa saja yang masih kurang pada suatu sistem penyediaan air minum berbasis masyarakat, sehingga dapat diberikan rekomendasi untuk memperbaiki sistem tersebut. Kerangka ini dapat pula digunakan sebagai daftar pengecekan dalam menyiapkan suatu sistem penyediaan air minum berbasis komunitas.

\section{Daftar Pustaka}

Adams, E. A., \& Zulu, L. C. (2015). Participants or customers in water governance? Community-public partnerships for peri-urban water supply. Geoforum, 65(July 2018), 112-124. doi:10.1016/j.geoforum.2015.07.017.

Agrawal, A. (2001). Common property institutions and sustainable governance of resources. World Development, 29(10), 1649-1672. doi:10.1016/S0305-750X(01)00063-8.

Agrawal, A., Brown, D. G., Rao, G., Riolo, R., Robinson, D. T., \& Bommarito, M. (2013). Interactions between organizations and networks in common-pool resource governance. Environmental Science and Policy, 25, 138-146. doi:10.1016/j.envsci.2012.08.004.

Agrawal, A., \& Chhatre, A. (2006). Explaining success on the commons: Community forest governance in the Indian Himalaya. World Development, 34(1), 149-166. doi:10.1016/j.worlddev.2005.07.013.

Akbar, R. J., \& Prabatmodjo, H. (2013). Implementasi partisipasi masyarakat dalam menanggapi implementasi PNPM mandiri perkotaan. Jurnal Perencanaan Wilayah Dan Kota, 3(1), 54-66.

Badan Informasi Geospasial (BIG). (2017). Geospasial untuk negeri. Retrieved from http://tanahair.indonesia.go.id/portal-web.

Badan Pengelola Sarana Penyediaan Air Minum dan Sanitasi (BPSPAMS). (2017). Persoalan keberlanjutan desadesa PAMSIMAS. Retrieved from http://new.pamsimas.org/Media.Php?Module=Detailberita\&Id=154\&Cated=26.

Badan Perencanaan dan Pembangunan Nasional (BAPPENAS). (2003). Pembangunan air minum dan penyehatan lingkungan berbasis masyarakat. Jakarta.

Bakker, K. (2008). The ambiguity of community: Debating alternatives to private-sector provision of urban water supply. Water Alternatives, 1(2), 236-252.

Bisung, E., Elliott, S. J., Schuster-Wallace, C. J., Karanja, D. M., \& Bernard, A. (2014). Social capital, collective action and access to water in rural Kenya. Social Science and Medicine, 119, 147-154. doi:10.1016/j.socscimed.2014.07.060.

Creswell, J. W. (2010). Research Design. Pendekatan Kualitatif, Kuantitatif dan Mixed. (S. Z. Qudsi, Ed.) (Ketiga). Yogyakarta: Pustaka Pelajar. (Original work published 1997).

Dickin, S., Bisung, E., \& Savadogo, K. (2017). Geoforum sanitation and the commons: The role of collective action in sanitation use. Geoforum, 86, 118-126. doi:10.1016/j.geoforum.2017.09.009.

Ducrot, R. (2017). When good practices by water committees are not relevant: Sustainability of small water infrastructures in semi-arid Mozambique. Physics and Chemistry of the Earth, 102, 59-69. doi:10.1016/j.pce.2016.08.004. 
Fisher, B., Kulindwa, K., Mwanyoka, I., Turner, R. K., \& Burgess, N. D. (2010). Common pool resource management and PES: Lessons and constraints for water PES in Tanzania. Ecological Economics, 69(6), 1253-1261. doi:10.1016/j.ecolecon.2009.11.008.

Hardin, G. (1968). The tragedy of the commons. Science, 162(June), 1243-1248. doi:10.1126/science.162.3859.1243.

Himpunan Penduduk Pemakai Air Minum (Hippam). (2016). Profil HIPPAM mandiri Arjowinangun. Malang: HIPPAM Mandiri Arjowinangun.

Hope, R. (2015). Is community water management the community's choice? Implications for water and development policy in Africa. Water Policy, 174), 664-678. doi:10.2166/wp.2014.170.

Kimbrough, E. O., \& Vostroknutov, A. (2015). The social and ecological determinants of common pool resource sustainability. Journal of Environmental Economics and Management, 72, 38-53. doi:10.1016/j.jeem.2015.04.004.

Lejano, R. P., \& Fernandez de Castro, F. (2014). Norm, network, and commons: The invisible hand of community. Environmental Science and Policy, 36, 73-85. doi:10.1016/j.envsci.2013.07.012.

Ostrom, E. (1990). Governing the Commons: The Evolution of Institutions for Collective Action. Cambridge: Cambridge University Press. Retrieved from wtf.tw/ref/ostrom_1990.pdf.

Ostrom, E. (2000). Collective action and the evolution of social norms. Journal of Economic Perspectives, 14(3), 137-158. doi:10.1080/19390459.2014.935173.

Ricks, J. I. (2016). Building participatory organizations for common pool resource management: Water user group promotion in Indonesia. World Development, 77, 34-47. doi:10.1016/j.worlddev.2015.08.014.

Schlager, E. (2004). Common-pool resource theory. In R. F. Durant, J. Fiorino, Daniel, \& R. O’Leary (Eds.), Environmental Governance Reconsidered. Cambridge, MA: MIT.

Schouten, T., \& Moriarty, P. (2003). Community water, community management: From system to service in rural areas. London.

Sugiyono. (2014). Metode Penelitian Kuantitatif, Kualitatif, dan $R \& D$. Bandung: Alfabeta.

United Nations International Children's Emergency Fund (UNICEF). (2010). Sustainability of Water Supply Infrastructures: A Good Practice from Guro District in Central Mozambique. Mozambique.

Zuka, S. (2013). Myths and realities in community management of common pool resources in Malawi: Social stratification as a negative side-effect of social capital. Journal of Natural Resources Policy Research, 5(4), 227-239. doi:10.1080/19390459.2013.826466. 